\title{
ПІДВИЩЕННЯ ЕФЕКТИВНОСТІ НАВЧАЛЬНОГО ПРОЦЕСУ ЗА РАХУНОК ВИКОРИСТАННЯ КОМП'ЮТЕРНИХ ТЕХНОЛОГІЙ
}

\author{
Т. В. Чорненька, С. О. Коноваленко \\ Горлівський медичний коледж \\ ДВНЗ «Тернопільський державний медичний університет \\ імені І. Я. Горбачевського МОЗ Украӥни»
}

\begin{abstract}
Мета написання даної статті полягає в тому, щоб розглянути, як комп’ютерні технології використовуються в навчальному процесі, і за рахунок чого підвищується ефективність засвоєння знань при використанні комп’ютерної техніки.
\end{abstract}

\section{THE IMPROVING OF THE EFFICIENCY OF THE EDUCATIONAL PROCESS THROUGH THE USE OF COMPUTER TECHNOLOGY}

\author{
T. V. Chornenka, S. O. Konovalenko \\ Horlivka Medical College \\ I. Horbachevsky Ternopil State Medical University
}

The purpose of writing this article is to explore how computer technologies are used in the educational process and thereby increasing the effectiveness of learning when using computer technology.

Вступ. На даному етапі розвитку суспільства відбувається всебічна його інформатизація. Одним із ії важливих напрямків $€$ новітні комп'ютерні технології. Наразі важко знайти сферу людської діяльності, де комп'ютерна техніка не знайшла б свого застосування. Ії̈ використання в освітніх процесах дозволило значною мірою вдосконалювати існуючі та створити багато нових форм і методів навчання. Серед інноваційних педагогічних технологій комп'ютерні займають одне з провідних місць, оскільки в світі неухильно зростає потік інформації, яку треба засвоювати при наявності браку часу. Не залишає сумнівів і їх перспективність, оскільки комп'ютерним технологіям властива різноманітність та багатогранність.

Можливості застосування комп'ютерних телекомунікацій в освіті стали предметом досліджень таких вчених, як Морзе Н. В., Кухаренко В. Н., Полат Е. С., Жук Ю. О., Моісєєвої М. В. та ін. [1].

Одним із завдань освітньої системи - підготовка фахівців, що вільно орієнтуються у освітньому інформаційному просторі, мають знання і навички щодо пошуку, обробки та зберігання інформації, використовуючи сучасні комп'ютерні технології. Цей

(c) Т. В. Чорненька, С. О. Коноваленко, 2016 напрямок вважається перспективним, адже в цілому освіта характеризується як велика система, якісне функціонування якої неможливе без використання сучасних телекомунікаційних і комп'ютерних засобів зберігання, опрацювання, передавання та подання інформації [3].

Основна частина. Однією з основних умов інтеграції у Болонський процес $є$ активне запровадження інформаційних освітніх технологій, тобто модель навчально-виховного процесу, де досягнення мети відбувається за рахунок найповнішого використання комп'ютерної техніки, комп'ютерних мереж і програмного забезпечення.

Комп'ютер під час підготовки й проведення занять може виконувати як функції робочого інструмента, так і вчителя. Як робочий інструмент він використовується для підготовки і зберігання тестових завдань, як тестовий або графічний редактор, обчислювальна машина з можливістю різноманітного оформлення результатів, засіб моделювання. У функції вчителя комп'ютер являє собою джерело інформації, посібник, тренера, засіб діагностики і контролю.

Комп'ютерні технології вносять істотні зміни і доповнення до навчальних завдань, що вирішуються 
завдяки традиційним підходам. 3'являються необхідність в моделюванні, плануванні, прогнозуванні, імітації різноманітних дій, зануренні у певне середовище, де студент, виконуючи певні дії, сам змінює навчальну ситуацію. Ця форма використання комп'ютера найперспективніша, вона спонукає студента до продуктивного мислення, модулюючи виробничі процеси та імітуючи майбутню професійну діяльність.

Комп'ютери можуть бути використані на усіх стадіях процесу навчання. Виходячи з методичних цілей, реалізація яких можлива лише за допомогою комп'ютерних засобів, можна виділити найбільш значні принципи комп'ютерного навчання:

1) принцип індивідуалізації і диференційного навчання;

2) принципи самоконтролю та контролю зі зворотним зв'язком, з діагностикою помилок і оцінювання результатів навчання;

3) принцип тренування в процесі засвоєння знань і самоконтролю;

4) принцип візуалізації навчальної інформації;

5) принципи створення і використання інформаційних баз даних і забезпечення доступу до мережі інформації;

6) принцип посилення мотивації навчання;

7) принцип інтенсифікації навчання;

8) принцип психологічної комфортності [2].

Комп'ютер має індивідуальну спрямованість навчання, що дає можливість кожному студенту обирати темп і рівень складності навчальної діяльності. Він дозволяє проводити адаптацію навчання до базової підготовки конкретного студента, до місця його проживання, стану здоров'я, матеріального становища.

Завдяки новим формам роботи, активізації навчання за рахунок використання і швидкозмінних форм надання інформації, значно підвищується мотивація студентів. Застосування комп'ютерної техніки дозволяє повністю ліквідувати одну з найважливіших причин негативного ставлення до навчання - відсутність позитивних результатів. Студент, працюючи з комп'ютером, отримує можливість довести до кінця рішення будь-якої задачі, оскільки йому надається допомога.

Комп'ютерні технології за рахунок можливості оперативно отримувати необхідні дані в достатньому обсязі, дозволяють значно збільшити інтенсифікацію навчального процесу, засвоїти набагато більше матеріалу, ніж це робиться за той самий час в умовах традиційного навчання.
Наукові дослідження показують, що люди засвоюють 20 \% почутого й 30 \% побаченого, але запам'ятовують більше 50 \% того, що бачили й чули одночасно. У навчальному процесі комп'ютер як засіб наочності, у сучасних умовах набув дуже великого значення. Він дозволяє побачити в динаміці багато процесів, надає можливість моделювати різноманітні ситуації і процеси, вибирати з ряду можливих рішень найбільш оптимальні, просто використовуватись для презентації навчального матеріалу. Це дозволяє подати навчальний матеріал як систему опорних образів, наповнених структурованою інформацією в алгоритмічному порядку. Інформаційна насиченість досягається одночасним гармонійним інтегруванням різних видів інформації (графічної, звукової, фото і відеоінформації). При цьому інформація сприймається різними каналами, що дозволяє ії засвоїти не лише у фактичному, а й в асоційованому вигляді. Наявність якісної наочності сприяє розвитку механізмів довготривалої пам'яті. Використання комп'ютерних моделей сприяє розвитку образного мислення і кращому засвоєнню матеріалу.

Безумовно, що однією з визначальних складових професійної підготовки фахівців $\epsilon$ рівень якості практичної підготовки, який визначається трьома складовими:

1) рівнем теоретичних знань;

2) володінням практичними навичками;

3) професійним вмінням.

Інтенсифікація навчального процесу за рахунок використання комп'ютерних систем дозволяє, не змінюючи загального терміну навчання, приділяти більше уваги саме практичним заняттям, відпрацюванню практичних навичок, формуванню професійних вмінь. Тільки той, хто вміє виконувати, а не лише знає, як виконувати, може почуватися захищеним на сучасному ринку праці і бути конкурентоспроможним.

Теоретичні знання здобувають під час лекцій та шляхом самостійного вивчення. Навички - це професійні дії, що доведені до автоматизму шляхом повторення вправ, тренінгу відповідно до алгоритму. Навички і теоретичні знання - це передумови для оволодіння професійними вміннями. Професійні вміння - здатність фахівця оперувати системою знань і практичних навичок у вирішенні завдань, ускладнених ситуацій.

Пацієнти завжди прагнуть, щоб медичну допомогу їм надавала кваліфікована медична сестра з високими професійними навичками, щоб вона була справжнім 
фахівцем своєї справи. У всьому світі для навчання медичних сестер та лікарів широко використовується «фантомний курс», що передбачає застосування різноманітних манекенів і муляжів. Однак найбільшої уваги заслуговує використання симуляторів - багатофункціональних комп'ютерних манекенів, які дозволяють моделювати практично будь-яку клінічну ситуацію. Симуляція ситуацій в медицині допомагає студентаммедикам вчитися, формує професійні вміння, розвиває критичне мислення. При цьому не створюється загроза життю чи здоров'ю пацієнта.

Оволодіння уміннями та навичками самостійно $\epsilon$ найважливішою умовою здійснення безперервної освіти. Індивідуальна робота студента $\epsilon$ не просто важливою формою навчального процесу, а повинна стати його основою [4]. У навчальних закладах останнім часом спостерігається тенденція до збільшення годин на самостійну роботу.

Розглянемо співвідношення кількості навчального часу, відведеного для вивчення теоретичного матеріалу, практичних занять і самостійної роботи на прикладі навчальної програми Горлівського медичного коледжу. Викладання дисципліни «Медсестринство в хірургії» з 2003 року змінилось таким чином (табл. 1).

таблиця 1. Співвідношення кількості навчального часу

\begin{tabular}{|l|c|c|c|}
\hline Роки & $2003^{*}$ & $2006^{* *}$ & 2011 \\
\hline Теорія & 30 & 57 & 50 \\
\hline Практика & 130 & 166 & 192 \\
\hline Самостійна робота & 83 & 107 & 136 \\
\hline Всього & 243 & 330 & 378 \\
\hline
\end{tabular}

Примітки: 1) * - у 2003 році навчальна програма була розрахована на дворічний термін;

2) ** - з 2006 року термін навчання складає три роки.

Варто зазначити, що в 2006 році самостійна робота студентів була більш націлена на вивчення теоретичного матеріалу. У програмі 2011 року основним завданням даної роботи стало відпрацьовування практичних навичок.

В організації самостійної роботи студентів можна виділити наступні можливості комп'ютерних технологій:

- забезпечення гнучкості навчального процесу за допомогою зміни форм і методів навчання;

- поєднання різних методик навчання для студентів різного рівня підготовки;

- варіювання об'єму та складності завдань;

- активізація пізнавальної діяльності за рахунок моделювання візуалізації навчального матеріалу, реалізації технічних можливостей комп'ютера;
- організація гнучкого управління навчальним процесом із забезпеченням безперервного зворотного зв'язку.

Значне місце в самостійній роботі займає використовування інтернет-ресурсів. Доступність великої кількості електронних статей, книг, довідкової літератури, електронних навчально-методичних розробок, які викладено на сайтах вищих навчальних закладів, безумовно розширюють творчий потенціал студентів. На даний час у Горлівському медичному коледжі працює комп'ютерний клас, де всі комп'ютери підключені до мережі «Інтернет». Це дозволяє значно підвищити якість та продуктивність аудиторної самостійної роботи.

Вільне володіння комп'ютером - одна з основних вимог нашого часу, що висувається до фахівців будьякого рівня та напрямку. Варто залучати студентів до процесу створення навчального матеріалу, різноманітних комп'ютерних навчальних або тестових програм. Процес творчості тут поєднується з необхідністю наявності базових знань. У Горлівському медичному коледжі цьому питанню приділяється багато уваги. На даному етапі ведеться робота зі створення комп'ютерних програм із завданнями для студентів відділення спеціальності «Сестринська справа»:

- зібрати набір інструментів для операції;

- розташувати загальний хірургічний інструмент за групами;

- вибрати препарати для гемостазу відповідно до виду кровотечі;

- визначити ступінь та площу опіку;

- провести порівняльну характеристику ушкодженої та здорової кінцівки.

Висновки. Використання в навчальному процесі комп'ютерних технологій не тільки сприяє розвитку самостійності та творчих здібностей у студентів, а й суттєво змінює саму технологію навчання. Вони трансформують негативне ставлення до навчання в позитивне, посилюють особисту спрямованість, сприяють ефективній орієнтації на професійну діяльність. Крім того, комп'ютерні технології забезпечують привабливу форму подачі навчального матеріалу, мають високу інформативну наповненість, дають можливість здійснювати оперативний обмін інформацією, надавати консультативну допомогу, організувати якісний контроль рівня засвоєння знань, що дозволяє значною мірою підвищити ефективність навчання. 


\section{ЛІТЕРАТУРА}

1. Євсєєва О. В. Впровадження інноваційних технологій у сучасному навчанні студентів заочного відділення / О. В. Євсєєва // Готуємо молодшого фахівця. - 2012. № 6. - С. 22-25.

2. Селевко Г. К. Энциклопедия образовательных технологий : в 2 т. / Г. К. Селевко. - М. : НИИ школьных технологий, 2006. - Т. 1. - 816 с.
3. Симоненко П. Використання комп'ютерних технологій під час викладання професійно орієнтованих дисциплін / П. Симоненко // Освіта. Технікуми, коледжі. 2012. - № 1/2. - С. 60-61.

4. Тарасенко К. М. Шляхи вдосконалення системи організації самостійної роботи студентів / К. М. Тарасенко, Н.К. Голубченко // Вища освіта в медсестринстві: проблеми і перспективи. - Житомир ; 2011. - С. 242.

Отримано 26.02.16 